\title{
Amicus briefs of the National Association of Consumer Advocates in Day v. Persels \& Associates, 729 F.3d 1309 (11th Cir. 2013)
}

Brian Wolfman

Georgetown University Law Center, wolfmanb@law.georgetown.edu

Docket No. 12-11887

http://ssrn.com/abstract=2425219

This paper can be downloaded free of charge from: http://scholarship.law.georgetown.edu/scb/74 
No. 12-11887

\title{
UNITED STATES COURT OF APPEALS FOR THE ELEVENTH CIRCUIT
}

\author{
MIRANDA L. DAY, for herself \\ and all persons similarly situated, \\ Plaintiffs-Appellees,
}

$$
\text { v. }
$$

RAYMOND GUNN, Interested Party-Appellant,

v.

PERSELS \& ASSOCIATES, LLC; RUTHER \& ASSOCIATES,LLC; LEGAL ADVICE LINE, LLC; JIMMY B. PERSELS; NEIL J. RUTHER; ROBYN R. FREEDMAN; and CAREONE SERVICES, INC., Defendants-Appellees.

On Appeal from the United States District Court for the Middle District of Florida

\section{BRIEF OF AMICUS CURIAE NATIONAL ASSOCIATION OF CONSUMER ADVOCATES}

Brian Wolfman

Institute for Public Representation

Georgetown University Law Center

600 New Jersey Avenue, NW

Washington, D.C. 20001

(202) 661-6582

Counsel for Amicus Curiae 


\section{Case: $12-11887$ Date Filed: 06/25/2012 Page: 2 of 53}

\section{CERTIFICATE OF INTERESTED PERSONS AND CORPORATE DISCLOSURE STATEMENT}

Under Federal Rule of Appellate Procedure 26.1 and this Court's

Rule 26.1-1, undersigned counsel for amicus curiae National Association of Consumer Advocates certifies that he believes that the Certificate of Interested Persons and Corporate Disclosure Statement accompanying the Brief of Appellant Raymond Gunn filed on June 18, 2012, is complete with the following exceptions:

Paladino, Victor (counsel for amici curiae)

The State of New York and other states (amici curiae)

ls/ Brian Wolfman

Brian Wolfman

Counsel for Amicus Curiae 


\section{STATEMENT REGARDING ORAL ARGUMENT}

Amicus curiae National Association of Consumer Advocates

agrees with appellant Gunn that oral argument would be useful in this

case. Amicus is raising jurisdictional and other arguments not raised by the named parties to this appeal. Counsel for amicus would participate in oral argument if the Court believes that would be helpful. 


\section{TABLE OF CONTENTS}

CERTIFICATE OF INTERESTED PERSONS. . . . . . . . . . . C-1

STATEMENT REGARDING ORAL ARGUMENT. . . . . . . . . . . i

TABLE OF CITATIONS. ................... iv

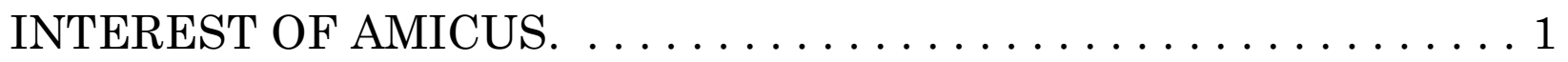

STATEMENT OF ISSUES. . . . . . . . . . . . . . . . . 2

SUMMARY OF ARGUMENT. . . . . . . . . . . . . . 2

ARGUMENT. ......................... 4

I. The Magistrate Judge Lacked Constitutional Authority

to Enter Final Judgment. . . . . . . . . . . . . . 4

A. The Question Whether the Magistrate

Judge Lacked Authority to Enter Final

Judgment is Jurisdictional and, Therefore,

Must Be Decided by This Court...........6 6

B. The Magistrate Judge Lacked

Constitutional Authority to Enter Final

Judgment in This Class Action. . . . . . . . . 7 
C. The Magistrate Judge Lacked Authority to Enter Final Judgment Because the Absent Class Members Were Not Given

Constitutionally Adequate Notice That a Magistrate Judge Had Been Given That Power. ......................... 18

D. Section 636(c) Is Facially Unconstitutional

Because It Allows Magistrate Judges to Wield the Judicial Power of the United States. . . . . . . . . . . . . . . . 22

II. A Court Should Never Defer to the Views or Reputation of Counsel in Deciding Whether to Approve a Class-Action Settlement. . . . . . . . . . . . . . . 29

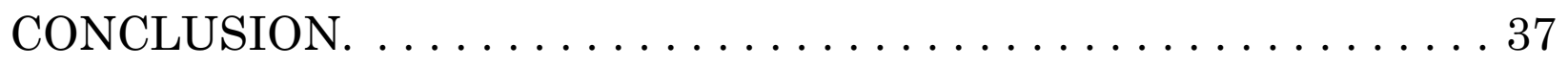
CERTIFICATE OF COMPLIANCE. . . . . . . . . . . . . . 39 CERTIFICATE OF SERVICE.................... 40 


\section{TABLE OF CITATIONS}

(Citations on which amicus primarily relies are preceded with an *.)

\section{CASES}

Adams v. Heckler,

794 F.2d 303 (7th Cir. 1986). . . . . . . . . . . . . . . 10

Bogard v. Cook,

586 F.2d 399 (5th Cir. 1978). . . . . . . . . . . . . . 21

Bolin v. Sears, Roebuck \& Co.,

231 F.3d 970 (5th Cir. 2000). . . . . . . . . . . . . . . . . 33

Boyd v. Bechtel Corp.,

485 F. Supp. 610 (N.D. Cal. 1979). . . . . . . . . . . . . . . 33

Brotherton v. Cleveland,

141 F. Supp. 2d 894 (S.D. Ohio 2001).. . . . . . . . . . . . . . 30

Canupp v. Liberty Behavioral Healthcare Corp.,

447 Fed. App'x. 976 (11th 2011). . . . . . . . . . . . . . 31

Commodity Futures Trading Commission v. Schor,

478 U.S. 833, 106 S. Ct. 3245 (1986). . . . . . . . . . . . 28 
Devlin v. Scardelletti,

536 U.S. 1, 122 S. Ct. 2005 (2002). . . . . . . . . . . . . 14

Dewey v. Volkswagen Aktiengesellschaft,

_ F.3d _, 2012 WL 1948970

(3d Cir. May 31, 2012)............... 7, 14, 15, 22

Fowler v. Jones,

899 F.2d 1088 (11th Cir. 1990)..................... 10

In re General Motors Corp. Pick-Up Truck Fuel Tank Products Liab.

Litig., 55 F.3d 768 (3d Cir. 1995).. . . . . . . . . . . . . 34-35

Geras v. Lafayette Display Fixtures, Inc.,

742 F.2d 1037 (7th Cir. 1984)... . 9 9, 12, 13, 22, 23, 24, 25, 26, 27 Hall v. Sharpe,

812 F.2d 644 (11th Cir. 1987)............... 11, 12, 13 Hansberry v. Lee,

311 U.S. 32, 61 S. Ct. 115 (1940). . . . . . . . . . . 11, 18 *Holmes v. Continental Can Co.,

706 F.2d $1144(11$ th 1983).................... 31, 32 
Kamilewicz v. Bank of Boston Corp.,

100 F.3d 1348 (7th Cir. 1996)..................... 34

Lehman Brothers Kuhn Loeb Inc. v. Clark Oil \& Refining Corp.,

739 F.2d 1313 (8th Cir. 1984) (en banc). . . . . . . . . 23, 25, 27

Lopez v. City of Santa Fe,

206 F.R.D. 285 (D.N.M. 2002).. . . . . . . . . . . . . . . 36

Marbury v. Madison,

5 U.S. (1 Cranch) $137(1803) \ldots \ldots \ldots \ldots \ldots \ldots \ldots \ldots . \ldots . \ldots . \ldots 29$

Martin v. Wilks,

490 U.S. 755, 109 S. Ct. 2180 (1989). . . . . . . . . . . 18

McNab v. J \& J Marine, Inc.,

240 F.3d 1326 (11th Cir. 2001). . . . . . . . . . . . . . . . 7

Mullane v. Central Hanover Bank \& Trust Co.,

339 U.S. 306 , 70 S. Ct. 652 (1950). . . . . . . . . . . . 19

Northern Pipeline Construction Co. v. Marathon Pipe Line Co.,

458 U.S. 50, 102 S. Ct. 2858 (1982). . . . . . 7, 11, 16, 23, 24, 28

*In re Nissan Motor Corp. Antitrust Litigation,

552 F.2d 1088 (5th Cir. 1977).................... 19-20 
Pacemaker Diagnostic Clinic, Inc. v. Instromedix, Inc.,

725 F.2d 537 (9th Cir. 1984) (en banc). . . . . . . . . 9, 11, 12 *Phillips Petroleum Co. v. Shutts,

472 U.S. 797, 105 S. Ct. 2965 (1985). . . . . . . . . 13, 19, 20 Roell v. Withrow,

538 U.S. 580, 123 S. Ct. 1696 (2003). . . . . . . . . . . . 17 Sinclair v. Wainwright,

814 F.2d 1516 (11th Cir. 1987)................. 9, 22 Steel Co. v. Citizens for a Better Environment,

523 U.S. 83, 118 S. Ct. 1003 (1998). . . . . . . . . . . . . 6 *Stern v. Marshall,

131 S. Ct. $2594(2011) \ldots \ldots \ldots \ldots \ldots \ldots \ldots \ldots$. . . . 26, 28, 28, 29 Thorogood v. Sears, Roebuck and Co., 627 F.3d 289 (7th Cir. 2010). . . . . . . . . . . . . . 33, 36 Trief v. Dun \& Bradstreet Corp.,

840 F. Supp. 277 (S.D.N.Y. 1993). . . . . . . . . . . . . 33 *Twigg v. Sears, Roebuck \& Co.,

153 F.3d 1222 (11th Cir. 1998). . . . . . . . . . . . . . . 19 
U.S. Postal Service v. Gregory,

534 U.S. 1, 122 S. Ct. 431 (2001). . . . . . . . . . . . . . 36

United States v. Raddatz,

447 U.S. 667, 100 S. Ct. 2406 (1980). . . . . . . . . . . . 28

In re Vitamins Antitrust Litigation,

305 F. Supp. 2d 100 (D.D.C. 2004). . . . . . . . . . . . . 30

Wattleton v. Ladish Co.,

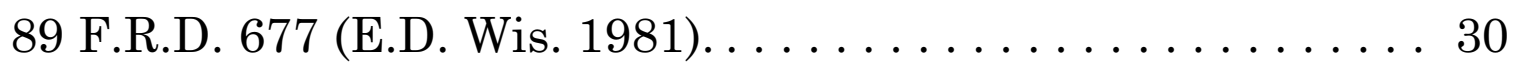

Weinberger v. Great Northern Nekoosa Corp.,

925 F.2d 518 (1st Cir. 1991). . . . . . . . . . . . . . . 33

Williams v. General Electric Capital Automobile Lease, Inc.,

159 F.3d 266 (7th Cir. 1998). . . . . . . . . . . . 14, 15, 22

Williams v. Vukovich,

720 F.2d 909 (6th Cir. 1983). . . . . . . . . . . . . . . . . 36

\section{CONSTITUTIONAL PROVISION, STATUTES, AND RULE}

U.S. Const. art. III, $\S 1 \ldots \ldots \ldots \ldots \ldots \ldots \ldots \ldots \ldots \ldots$

28 U.S.C. $\S 631(a) \ldots \ldots \ldots \ldots \ldots \ldots \ldots \ldots \ldots \ldots \ldots \ldots, 24$

28 U.S.C. $\S 631(\mathrm{e}) \ldots \ldots \ldots \ldots \ldots \ldots \ldots \ldots \ldots \ldots \ldots \ldots \ldots$ 
28 U.S.C. $\S 634(b) \ldots \ldots \ldots \ldots \ldots \ldots \ldots \ldots \ldots$

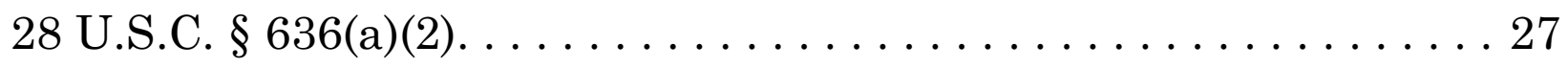

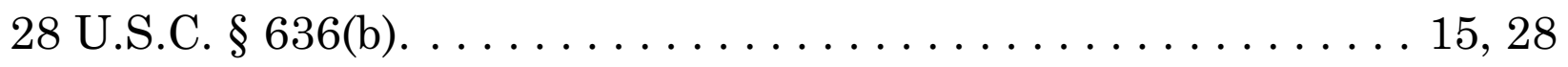

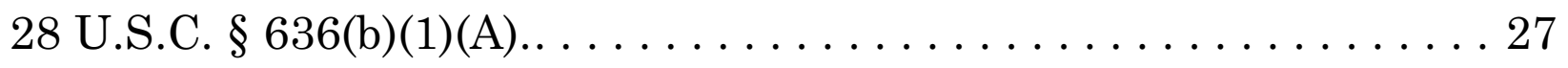

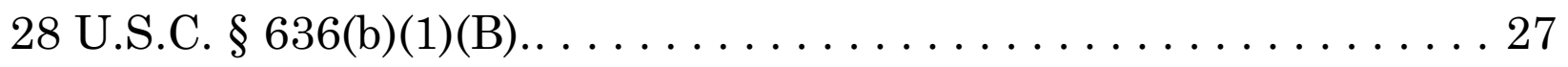

28 U.S.C. $\S 636(\mathrm{c}) . \ldots \ldots \ldots \ldots \ldots \ldots \ldots \ldots \ldots \ldots \ldots \ldots \ldots \ldots \ldots \ldots$

28 U.S.C. $\S 636(c)(3) \ldots \ldots \ldots \ldots \ldots \ldots \ldots \ldots \ldots \ldots \ldots \ldots \ldots \ldots \ldots$

29 U.S.C. $\S 216(b) \ldots \ldots \ldots \ldots \ldots \ldots \ldots \ldots \ldots \ldots$

Fed. R. Civ. P. 73(b)(2). . . . . . . . . . . . . . . . . . . . 10

\section{LEGISLATIVE HISTORY}

S. Rep. No. 96-74 (1979), reprinted in

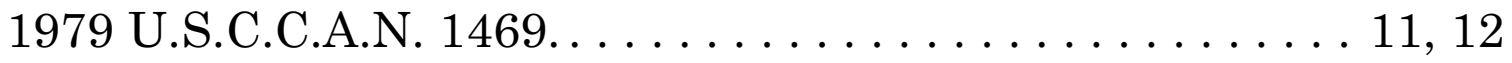

\section{MISCELLANEOUS}

Hart \& Wechsler's The Federal Courts and

the Federal System (6th ed. 2011 Supp.). . . . . . . . 16, 28

National Association of Consumer Advocates,

Standards and Guidelines for Litigating and Settling Consumer

Class Actions, 255 F.R.D. 215 (2d ed. 2009). . . . . . . . . . 1, 36 
Case: 12-11887 Date Filed: 06/25/2012 Page: 12 of 53

Note, Article III Constraints and the Expanding Civil Jurisdiction of

Federal Magistrates: a Dissenting View,

88 Yale L.J. 1023 (1979).. . . . . . . . . . . . . . . . 25-26 


\section{INTEREST OF AMICUS}

This brief is filed by the National Association of Consumer

Advocates ("NACA") with the parties' consent. NACA is a nationwide, non-profit corporation whose over 1,700 members are private, public sector, legal services, and non-profit lawyers, law professors, and law students whose primary practices or interests involve consumer protection. NACA is dedicated to furthering the ethical representation of consumers.

Toward that end, NACA has issued its Standards and Guidelines for Litigating and Settling Consumer Class Actions, the revised second edition of which is published at 255 F.R.D. 215 (2009). The Standards and Guidelines seek to promote and preserve the class action-which NACA believes is a critical tool for consumer justice—by guarding against its misuse. NACA believes that the decision below undermines the class-action device to the detriment of consumers in two respects: by employing a magistrate judge to enter final approval of a class-action settlement contrary to constitutional requirements, and by 
deferring to class counsel's views and reputation. ${ }^{1}$

\section{STATEMENT OF ISSUES}

1. Whether the magistrate judge lacked constitutional authority to enter the final judgment below.

2. Whether a court may ever defer to the views or reputation of class-action lawyers in approving a class-action settlement.

\section{SUMMARY OF ARGUMENT}

I. Through life tenure and a ban on compensation reduction, Article III of the Constitution ensures that citizens have independent federal judges to adjudicate their rights. Though parties may waive some constitutional protections, any waiver must be exercised freely. Without voluntary consent from absent class members, entry of a final judgment approving a class-action settlement by a non-Article III magistrate judge under 28 U.S.C. $§ 636(c)$ is unconstitutional because the absentees cannot freely relinquish their rights to an Article III

\footnotetext{
${ }^{1}$ Under Federal Rule of Appellate Procedure 29(c)(5), amicus certifies that no party's counsel authored this brief in whole or in part and that no party, party's counsel, or other person other than amicus or its counsel contributed money intended to fund the preparation or submission of the brief.
} 
judge. Moreover, even if section 636(c) were constitutional when applied to class actions generally, in this case, the settlement cannot bind the class because the absentees lacked constitutionally adequate notice that they would be surrendering their constitutional rights to be heard by an Article III judge.

More broadly, section 636(c) is facially unconstitutional because it grants magistrate judges power to enter final judgment that the Constitution bestows only on Article III judges. Section 636(c) upsets the constitutional system of checks and balances by removing the safeguards that ensure an independent judiciary. This problem cannot be cured by the parties' consent because non-parties often have a profound interest in a case's outcome and, thus, in an independent judiciary.

II. In approving the class-action settlement below, the magistrate judge deferred to class counsel's reputation and their views on the settlement. Not unlike our Article III concerns, any such deference undermines the court's role as an independent decision maker. The magistrate judge deferred because he thought it problematic to substitute his judgment for counsel's judgment. But a court's role is to 
substitute its independent judgment for that of the lawyers appearing before it, particularly in the class-action settlement context, where the court must guard against collusion and act as a fiduciary for the class.

\section{ARGUMENT \\ I. The Magistrate Judge Lacked Constitutional Authority to Enter Final Judgment.}

NACA believes that the magistrate judge lacked constitutional authority to enter final judgment in this case. The facts relevant to that issue are straightforward. On May 20, 2011, all named parties consented to refer the case to a United States magistrate judge to conduct all proceedings and enter final judgment. Doc. 90. Plaintiff's counsel consented on behalf of named plaintiff Miranda Day only. See $i d$. At that point, the class had not been certified, and, therefore, plaintiff's counsel lacked authority to act on anyone else's behalf. The consents were executed under 28 U.S.C. § 636(c), which provides that "[u]pon consent of the parties," a magistrate judge "may conduct any or all proceedings in a jury or nonjury civil matter and order the entry of judgment in the case, when specifically designated to exercise such jurisdiction by the district court or courts he serves.” On May 23, 2011, 
U.S. District Judge Virginia M. Hernandez Covington referred the case to a magistrate judge for all further proceedings and entry of final judgment. Doc. 90 .

On September 20, 2011, the parties entered the class-action settlement challenged in this appeal. See Doc. 110-1; see also Doc. 1503. As part of that settlement, the named plaintiff and the defendants agreed that the case could be certified as a class action under Federal Rule of Civil Procedure 23(b)(3). See Doc. 110-1, at 10.

The magistrate judge granted the parties' motion for preliminary approval of the settlement, see Docs. $110 \& 112$, which included approval of a notice to be sent to the class. Doc. 111-1. The class notice did not explain that each class member had a right to proceed before an Article III judge nor that Miranda Day earlier had purported to extinguish those rights by consenting to the magistrate judge. The only reference to the words "magistrate judge" was on page seven of the eight-page notice, and there the notice stated only that a final approval hearing would be held in front of the magistrate judge. $I d$. at 7 . On the next page, however, the notice admonished the 
absentees that they should not contact “THE JUDGE'S

CHAMBERS.” Id. at 8 (emphasis in original). Otherwise, the notice referred repeatedly to "the Court," but not to the magistrate judge.

\section{A. The Question Whether the Magistrate Judge Lacked Authority to Enter Final Judgment is Jurisdictional and, Therefore, Must Be Decided by This Court.}

Because federal courts are courts of limited jurisdiction, "[e]very federal appellate court has a special obligation to 'satisfy itself not only of its own jurisdiction, but also that of the lower courts in a cause under review,' even though the parties are prepared to concede it." Steel Co. v. Citizens for a Better Env't, 523 U.S. 83, 95, 118 S. Ct. 1003, 1013 (1998) (citations omitted). NACA is questioning the magistrate judge's authority to enter final judgment approving the settlement. This argument was not raised by any named party or any objector. This Court is nevertheless required to consider it now because it presents the question whether the magistrate judge had jurisdiction to enter final judgment. See 28 U.S.C. § 636(c)(3) (“The consent of the parties allows a magistrate judge ... to exercise civil jurisdiction ... ." (emphasis added)). This Court has held that the question whether 
section 636(c)'s statutory requirements have been satisfied is a "jurisdictional question" that should be raised sua sponte. McNab v. J \& J Marine, Inc., 240 F.3d 1326, 1328 (11th Cir. 2001). Whether and in what circumstances 28 U.S.C. $§ 636(c)$ can constitutionally extend to class actions is likewise a jurisdictional question that must be resolved by this Court. See Dewey v. Volkswagen Aktiengesellschaft, F.3d _, 2012 WL 1948970, *7 (3d Cir. May 31, 2012).

\section{B. The Magistrate Judge Lacked Constitutional Authority to Enter Final Judgment in This Class Action.}

1. Article III of the Constitution vests the federal judicial power in the Supreme Court and "such inferior Courts" as Congress chooses to establish. U.S. Const. art. III, $\S 1$. It goes on to protect judicial independence by affording federal judges life tenure during good behavior and prohibiting Congress from reducing their salaries. Id. The Framers included these protections in Article III to ensure that an impartial judiciary would adjudicate the rights of citizens. N. Pipeline Constr. Co. v. Marathon Pipe Line Co., 458 U.S. 50, 58, 102 S. Ct. 2858, 
$2864-65(1982)^{2}$

The magistrate judge who entered final judgment below is not an Article III judge. Magistrate judges are appointed to terms of either four or eight years by the judges of the district court in which the magistrate judge is selected to serve. 28 U.S.C. $§ 631(\mathrm{a}),(\mathrm{e})$. An act of Congress prohibits reduction in their salaries during this term, see id. $\S 634(\mathrm{~b})$, but Congress could remove this prohibition without offending the Constitution. Moreover, because magistrate judges may be (but need not be) reappointed, they lack the independence that Article III judges gain from the knowledge that, once appointed, others do not hold the key to their continued employment.

The magistrate judge entered final judgment below under 28 U.S.C. $§ 636(\mathrm{c})$, which permits a magistrate judge to conduct all proceedings in a civil case, and to enter final judgment, but only "upon consent of the parties." Id. As we now explain, because entering final judgment under $\S 636(\mathrm{c})$ deprives absent class members of their rights to adjudicate their claims before independent judges who enjoy the

${ }^{2}$ All citations to Northern Pipeline are to Justice Brennan's fourjustice plurality opinion. 
protections of Article III without their consent, the statute is unconstitutional as applied to class actions, at least in the circumstances presented here, where the absent class members have not consented. ${ }^{3}$

2. The Supreme Court has never addressed whether section 636(c) is consistent with Article III, but it has withstood constitutional challenge in the circuit courts in non-class-action cases, including in this Court. See Sinclair v. Wainwright, 814 F.2d 1516, 1519 (11th Cir. 1987); but see infra Part I.D (arguing that section 636(c) is facially unconstitutional). The decisions upholding section 636(c) have placed great weight on its consent requirement. See, e.g., Geras v. Lafayette Display Fixtures, Inc., 742 F.2d 1037, 1041-42 (7th Cir. 1984); Pacemaker Diagnostic Clinic, Inc. v. Instromedix, Inc., 725 F.2d 537, 542-43 (9th Cir. 1984) (en banc). As this Court has put it,

${ }^{3}$ Absent class members could provide the individual consent demanded by section 636(c) in an opt-in class action, such as that authorized under the Fair Labor Standards Act, 29 U.S.C. § 216(b). Moreover, in the standard Rule 23(b)(3) opt-out class action, consent might be sought from class members in conjunction with the distribution of class relief. That was impossible here because the settlement provides no relief to the absent class members. 
"valid consent is the linchpin of the constitutionality of ... $§ 636(c) . "$

Fowler v. Jones, 899 F.2d 1088, 1093 (11th Cir. 1990) (quoting Adams

v. Heckler, 794 F.2d 303, 307 (7th Cir. 1986)) (internal quotation marks omitted).

The consent requirement seeks to legitimate what would otherwise be the unconstitutional exercise of the judicial power by magistrate judges. See, e.g., Fowler, 899 F.2d at 1093 (reversing judgment because magistrate conducted trial without parties' consent). In an ordinary case, the parties indicate their consent by signing a waiver that informs them of their absolute right to have their case tried by an Article III judge. See Fed. R. Civ. P. 73(b)(2). Here, the defendants and the named plaintiff signed a waiver through individually retained counsel. Doc. 90. The absent class members, however, did not.

3. To be sure, the efficient administration of class-action lawsuits requires that lawyers and representative plaintiffs make some decisions on the class's behalf. But this deviation from the ordinary relationship between lawyers and their clients has limits. A procedure 
will be invalidated "in those cases where it cannot be said that the procedure adopted, fairly insures the protection of the interests of absent parties who are to be bound by it." Hansberry v. Lee, 311 U.S. 32, 42, 61 S. Ct. 115, 118 (1940). The absent class members' rights to an adjudication before an Article III judge involves an interest guarded by the Constitution. Northern Pipeline, 458 U.S. at 58, 102 S. Ct. at 2864. The procedure at issue here-the application of section 636(c) in class-action suits—does not "fairly insure[" that this interest is protected because it allows a non-Article III judge to adjudicate the rights of absent class members without their consent. Section 636(c) is, therefore, unconstitutional as applied to class actions.

This conclusion is buttressed by the understanding that, to be constitutional, consent under section 636(c) must be voluntary. Hall v. Sharpe, 812 F.2d 644, 647 (11th Cir. 1987) (noting that "voluntary consent is crucial to [section 636(c)'s] procedure") (emphasis added); see also Pacemaker, 725 F.2d at 543 ("The waiver of personal rights must, of course, be freely and voluntarily undertaken."); S. Rep. No. 96-74, at 5 (1979), reprinted in 1979 U.S.C.C.A.N. 1469, 1473 ("The Bill clearly 
requires the voluntary consent of the parties."). Both the Congress that enacted section 636(c) and the courts that have upheld it had reservations about the possibility that litigants would be coerced into abandoning their right to an Article III judge. See id.

This Court has recognized that a robust consent requirement is necessary to "ensure[] against the wholesale delegation of certain classes of cases and discrimination among classes of litigants." Hall, 812 F.2d at 647; see also Pacemaker, 725 F.2d at 554 (Schroeder, J., dissenting) (expressing concern about economic coercion of lessadvantaged litigants). The Seventh Circuit expressed a similar concern in a caveat to its decision upholding section 636(c): "We do not believe that reference of civil matters to magistrates can be sustained against constitutional challenge unless an alternative of trial before an Article III judge is maintained for all litigants as a realistic and viable alternative." Geras, 742 F.2d at 1042 (emphasis added).

Because class actions operate through vicarious representation, in which neither the named plaintiff nor the lawyer consult with the absentees (let alone obtain informed consent to act on their behalf), the 
named plaintiff's consent cannot guard against coercion. Allowing class actions to proceed before magistrate judges thus illustrates the concern, articulated by the Seventh Circuit in Geras, that litigants will be forced before a magistrate judge against their interests and without a "realistic and viable" alternative to proceed before an Article III judge. See id.

Moreover, class actions allow plaintiffs to pool their small claims and overcome the otherwise prohibitive cost of litigation. Phillips Petroleum Co. v. Shutts, 472 U.S. 797, 809, 105 S. Ct. 2965, 2973 (1985). Absentees, then, may have no viable alternative to the class action before a magistrate judge who has been forced on them, without their consent, by the named representative. In this way, section 636(c) discriminates "among classes of litigants," Hall, 812 F.2d at 647, by creating a framework in which absentees either surrender their rights to an Article III judge or effectively lose their ability to vindicate their rights at all.

4. NACA acknowledges that two courts of appeals have rejected challenges to class-action settlements on the ground that they were 
approved by magistrate judges without the absentees' consent. See Dewey, 2012 WL 1948970, *7; Williams v. General Elec. Capital Auto Lease, Inc., 159 F.3d 266, 268-70 (7th Cir. 1998). In general, these decisions are inapposite because they concern mainly the statutory question whether absent class members are "parties" that must consent within the meaning of section 636(c), not the constitutional question presented here whether absentees may be bound by a magistrate judge's final judgment if they have not personally consented (even assuming section 636(c) does not require such consent). ${ }^{4}$

Dewey and Williams appear to have been motivated in large part

${ }^{4}$ We believe that under Devlin v. Scardelletti, 536 U.S. 1, 122 S. Ct. 2005 (2002) — which post-dates the Seventh Circuit's ruling in Williams and held that absent class members are "parties" entitled to appeal approval of a class-action settlement-absent class members are "parties" who must provide consent under section 636(c). After all, what was "most important" to Devlin's holding was that, without the right to appeal, absentees would be bound to a decision with which they disagreed. See id. at 10-11, $122 \mathrm{~S}$. Ct. at 2011. That reasoning applies equally here because, without a right to consent individually, absentees are bound to the named plaintiff's relinquishment of their rights to an adjudication before an Article III judge. Thus, this Court could decide the section 636(c) question on statutory grounds and avoid the constitutional issues. 
by what they viewed as the "radical result" that would be wrought by a ruling that magistrate judges lack authority to enter final judgment in most or all class actions. Dewey, 2012 WL 1948970, *7; Williams, 159 F.3d at 269. That reasoning is at odds with both courts' acknowledgments that an absent class member may intervene and demand that an Article III judge preside, which would effectively override the named plaintiff's consent to a magistrate judge. Dewey, 2012 WL 1948970, *7; Williams, 159 F.3d at 269.

In any event, those courts' concerns are misplaced. Undersigned counsel has been involved in dozens of class actions over the last two decades, and, in his experience, only rarely do the named parties consent to a magistrate judge's entry of final judgment under section 636(c). Moreover, under the ruling sought here by NACA, magistrate judges would still be available in class actions to exercise their many functions under 28 U.S.C. $§ 636(b)$, including recommending the final approval of a class-action settlement to an Article III district judge. But the fundamental answer to the concerns expressed by Dewey and Williams is that the courts have not shied away from the 
consequences of rulings enforcing Article III principles even when they have "radically" overridden congressional expedients. Northern Pipeline, for instance, invalidated the entire federal bankruptcy scheme because non-Article III judges had been given authority to decide all manner of cases that the Constitution assigns solely to Article III judges. 458 U.S. 50, 102 S. Ct. 2858. And, just last year, in Stern v. Marshall, 131 S. Ct. 2594 (2011), a decision that appears to have far-reaching consequences, the Court reminded Congress, again in the bankruptcy context, that it generally may not assign the business of Article III courts to decision makers who lack Article III protections. See generally Hart \& Wechsler's The Federal Courts and the Federal System 26-31 (6th ed. 2011 Supp.).

\section{Alternatively, the entry of final judgment here was} unconstitutional because Miranda Day's consent to the magistrate judge was entered solely on her own behalf, see Doc. 90 (May 23, 2011), well before she had authority to act on the class members' behalf, which did not occur until the magistrate judge certified the class as part of his settlement approval. Doc. 157 (Mar. 12, 2012); see 
also Doc. 112, at 3 (Sept. 29, 2011) (appointing class counsel). Thus, even assuming (incorrectly) that Miranda Day or her lawyers later possessed the authority as representatives of a certified class to consent to the entry of final judgment on behalf of the class members, they did not have that authority at the time of the consent. The argument that the absentees' "consented" to the entry of a final judgment by the magistrate judge necessarily depends on the useful fiction of representation created by class certification. It stretches that fiction to fantasy if the absentees' "consent" is deemed to have been provided before any class existed. Put another way, although consent to a magistrate judge may be implied by the parties' actual conduct, see Roell v. Withrow, 538 U.S. 580, 123 S. Ct. 1696 (2003), it cannot be manufactured out of whole cloth.

$$
\text { * * * }
$$

In sum, the decision of a magistrate judge approving a classaction settlement cannot bind absent class members who have not individually consented to the entry of final judgment by the magistrate judge. The decision below should be reversed for that reason alone. 


\section{The Magistrate Judge Lacked Authority to Enter} Final Judgment Because the Absent Class Members Were Not Given Constitutionally Adequate Notice That a Magistrate Judge Had Been Given That Power.

Even if section 636(c) is constitutional as applied to class actions generally, it was not employed constitutionally here because the absentees were not notified that they would be relinquishing their right to an Article III decision maker and that a magistrate judge would enter final judgment. For this reason, the absentees' due process rights were violated, and the decision below should be reversed.

In ordinary bi-polar litigation, "[i]t is a principle of general application in Anglo-American jurisprudence that one is not bound by a judgment in personam in a litigation in which he is not designated as a party or to which he has not been made a party by service of process." Hansberry, 311 U.S. at 40, 61 S. Ct. at 117; see also Martin v. Wilks, 490 U.S. 755, 761-62, 109 S. Ct. 2180, 2184 (1989). Class litigation is a "recognized exception" to that general rule. Hansberry, 311 U.S. at 41, 61 S. Ct. at 118. An absent class member is neither “designated" by name as a party nor served with process. For 
absentees, a different, but no less important, set of due process requirements apply before a class judgment can bind them.

In Phillips Petroleum Co. v. Shutts, 472 U.S. at 811-12, 105 S. Ct. at 2974, the Supreme Court described the "minimal procedural due process protections" necessary to "bind an absent plaintiff concerning a claim for money damages or similar relief." In particular, "[t]he plaintiff must receive notice plus an opportunity to be heard and participate in the litigation ... . The notice should describe the action and the plaintiffs' rights in it." Id. (quoting Mullane v. Central Hanover Bank \& Trust Co., 339 U.S. 306 314-15, 70 S. Ct. 652, 657 (1950) (emphasis added)). Controlling authority establishes that a class judgment may not be accorded binding effect if the class-action notice is not exacting in how it describes the claims and the plaintiffs' rights in the litigation. See Twigg v. Sears, Roebuck \& Co., 153 F.3d 1222, 1227-28 (11th Cir. 1998) (authorizing collateral attack on class-action settlement by absentee because although settlement itself may have covered absentee's claims, the settlement notice did not adequately disclose that the claims were covered); In re Nissan Motor Corp. 
Antitrust Litig., 552 F.2d 1088, 1103-05 (5th Cir. 1977) (finding classaction notice inadequate when it omitted terms of proposed settlement because for absentees "[t]his will be their primary, if not exclusive, source of information for deciding how to exercise their rights"). ${ }^{5}$

Here, the class notice did not come close to meeting what due process demands regarding the absentees' rights to an Article III decision maker. The class notice nowhere explained that Miranda Day had purported to relinquish the class members' rights to an Article III judge (much less that the class members possessed those rights). Indeed, as noted earlier (at 5), the only reference to the words "magistrate judge" was buried on page seven of the eight-page notice. Doc. 111-1, at 7. There, the notice stated only that a final approval hearing would be held in front of the magistrate judge. That was followed, confusingly, on the next page with an admonition that the absentees should not contact "THE JUDGE'S CHAMBERS,"

${ }^{5}$ Due process also requires that absentees be allowed to opt out of class actions seeking money damages. See Shutts, 472 U.S. at 812, 105 S. Ct. at 2974. The notice and opt-out rights work in tandem, as an opportunity to opt out is meaningless if the absentees are unaware of the rights at stake. 
suggesting that someone other than the magistrate judge was involved in the case. $I d$. at 8 (italics added). Adding the notice's repeated references to the "Court," a reader of the notice might well be confused about the identity of the decision maker.

We realize that the readers of a class notice are lay people, not lawyers, and, therefore, it is equally likely that the notice, rather than confusing the class members, conveyed nothing to them about their rights to an adjudication before an Article III decision maker. And, it was that omission, if not the confusing nature of the notice standing alone, that created the due process violation. See Bogard v. Cook, 586 F.2d 399, 408-09 (5th Cir. 1978) (refusing to give preclusive effect to class judgment because notice omitted express reference to the type of claims pursued by class member in subsequent suit). Put another way, the absentees could have had no idea that Miranda Day was proposing to give away their rights to an Article III decision maker unless they were told about it.

Moreover, as noted above (at 15), both Dewey and Williams acknowledge that absent class members may intervene and demand 
that an Article III judge preside, overriding the named plaintiff's consent to a magistrate judge. 2012 WL 1948970, *7; 159 F.3d at 269. That acknowledgment makes all the more important a notice clearly informing the absentees that the named plaintiff proposes to release their right to an Article III judge. A class member would not intervene to protect a right that she did not know the named plaintiff was proposing to relinquish.

For these reasons as well, the decision below should be reversed.

\section{Section 636(c) Is Facially Unconstitutional Because It Allows Magistrate Judges to Wield the Judicial Power of the United States.}

The previous sections of this brief concern the constitutionality of section 636(c) as is applies to unconsenting class members. This Court could go further and revisit its ruling in Sinclair, 814 F.2d 1516, which upheld the constitutionality of section 636(c) in the non-class-action context. Sinclair did not itself analyze the issue, but instead cited rulings of other circuits, finding them "persuasive." Id. at 1519. Despite the "unbroken phalanx of ... authority" sustaining section 636(c) against constitutional challenge, Geras, 742 F.2d at 1045 
(Posner, J., dissenting), we are convinced that section 636(c) oversteps Article III bounds in allowing a magistrate judge to wield the judicial power of the United States by entering final judgment. See id. at 104554; see also Lehman Bros. Kuhn Loeb Inc. v. Clark Oil \& Refining Corp., 739 F.2d 1313, 1319-20 (8th Cir. 1984) (en banc) (Arnold, J., dissenting).

As noted above, courts upholding section 636(c) have focused on consent as the "linchpin" of the statute's constitutionality. This focus assumes that Article III is concerned solely with individual litigants' rights of access to an independent judge. To be sure, this is an important interest. See Northern Pipeline, 458 U.S. at 58, 102 S. Ct. 2864. But Article III "is concerned with more than fairness to the parties in any given case." Lehman Bros., 739 F.2d at 1319 (Arnold, J., dissenting). Allowing magistrate judges to enter final judgments also (1) disrupts the structural checks and balances established by the Constitution and (2) affects the rights of unconsenting citizens who are not parties to the suit. See id. 
Cases upholding section 636(c) dismiss the separation-of-powers concerns on the ground that magistrate judges are appointed by Article III judges. See 28 U.S.C. § 631(a). So, the argument goes, magistrate judges are not susceptible to pressure by the executive or legislative branches. See, e.g., Geras, 742 F.2d at 1043. This argument founders on several fronts.

First, it ignores the most likely forms of congressional encroachment during a magistrate judge's tenure (regardless of who holds the appointment power). Article III's tenure and salary protections recognize that the judiciary could be controlled by the other branches if they retained control over the judges' employment or salaries. Northern Pipeline, 458 U.S. at 59, 102 S. Ct. at 2865. Although the judiciary may control a magistrate judge's chances for reappointment, Congress can eliminate a magistrate judge's position altogether, can reduce her salary from one term to the next, or can, with an act repealing the current statutory (that is, non-constitutional) prohibition, reduce her salary now. See Geras, 742 F.2d 1052-53 (Posner, J., dissenting). 
Second, that Article III judges appoint magistrate judges defies the Constitution's separation of powers even before they begin to serve. Appointment by the judiciary encroaches on the President's power to appoint judges and the Senate's power to confirm them. Lehman Bros., 739 F.2d at 1319 (Arnold, J., dissenting).

Finally, the Constitution is concerned with intra-branch checks and balances in addition to inter-branch checks and balances. The lifetime-appointment protection is important, among other reasons, because it protects district court judges from appellate judges and appellate judges from Supreme Court Justices. "Appellate judges can reverse district judges, can mandamus them, can criticize them, can remand a case to another judge, but cannot fire district judges, cow them, or silence them-cannot prevent them from making independent judgments and expressing independent views." Geras, 742 F.2d at 1053 (Posner, J., dissenting). Magistrate judges do not have the same independence because, though they enter final judgments in the district court, they rely on district court judges for their reappointment. See Note, Article III Constraints and the Expanding 
Civil Jurisdiction of Federal Magistrates: a Dissenting View, 88 Yale L.J. 1023, 1056-58 (1979) (detailed discussion of intra-branch pressures on magistrates that undermine Article III values).

Meanwhile, in addition to doing nothing to ease these separationof-powers concerns, the consent requirement does not go far enough to protect the individual rights that an independent judiciary is meant to vindicate. All citizens, not just those who have consented, have a stake in "the quality of the administration of federal [and state] law." Geras, 742 F.2d at 1051 (Posner, J., dissenting). Apart from this generalized interest in an independent judiciary, nonparties are often affected profoundly by a case's outcome. District court cases can have farreaching consequences, and when, for example, a magistrate judge rules on a statute's constitutionality, the result affects many others beyond the parties who relinquished their rights to an Article III judge. See id.

Nor can section 636(c) be justified on the theory that magistrate judges enter final judgments as "adjuncts" to Article III judges. Though most courts upholding section 636(c) have focused on consent, 
others have advanced the additional rationale that magistrates are "adjuncts" to address the separation-of-powers concerns that individual consent cannot cure. See Lehman Bros., 739 F.2d at 131516.

Magistrate judges are properly described as adjuncts when they administer oaths, 28 U.S.C. $§ 636(a)(2)$, rule on pretrial matters, $i d$. $\S 636(\mathrm{~b})(1)(\mathrm{A})$, and conduct hearings, $i d . \S 636(\mathrm{~b})(1)(\mathrm{B})$. But when they rule finally in a civil case, "[t]hey are deciding who should win cases, and entering judgments accordingly." Lehman Bros., 739 F.2d at 1319 (Arnold, J., dissenting). This is the exercise of "the judicial power in the most basic sense." Id.; accord Geras, 742 F.2d at 1047 (Posner, J., dissenting).

Again, we acknowledge that this Court has upheld section 636(c), and we emphasize that the earlier sections of this brief provide narrower bases for reversal. But the Supreme Court's recent decision in Stern, 131 S. Ct. 2594, suggests that this Court's earlier ruling should be revisited. First, Stern focused heavily on the separation-ofpowers concerns of the Northern Pipeline plurality, $i d$. at 2609-10, 
which in turn had noted that allowing magistrates to issue recommendations under 28 U.S.C. $§ 636(\mathrm{~b})$ is constitutional because Article III judges retain final decision making authority. Northern Pipeline, 458 U.S. at 79, 102 S. Ct. at 2875 (discussing United States $v$. Raddatz, 447 U.S. 667, 100 S. Ct. 2406 (1980)). Stern thus draws into question the continuing importance of litigant-specific concerns such as consent. See Commodity Futures Trading Comm'n v. Schor, 478 U.S. 833, 867, 106 S. Ct. 3245, 3266 (1986) (Brennan, J., dissenting) (explaining why "consent is irrelevant to Article III analysis"); Hart \& Wechsler's, supra, at 30 (noting that Stern's separation-of-powers focus “echoes" Justice Brennan's Schor dissent).

Second, Stern rejected the argument that bankruptcy judges, who, like magistrate judges, do not receive the protections of Article III, are adjuncts to district court judges. The Court found that bankruptcy judges are not adjuncts because they "resolve '[a]ll matters of fact and law in whatever domains of the law to which' the parties' [claims might lead.” 131 S. Ct. at 2618-19 (quoting Northern Pipeline, 458 U.S. at 91, 102 S. Ct. at 2882) (first alteration in original). So, too, 
does a magistrate judge exercising her authority under section 636(c). The Court in Stern was swayed by the extent of the bankruptcy judge's final decision-making authority: "[A] bankruptcy court ... has the power to enter 'appropriate orders and judgments'-including final judgments—subject to review only if a party chooses to appeal." Id. at 2619 (citation omitted). That describes precisely the authority that a magistrate judge exercises under section 636(c)—that is, a magistrate judge, when authorized to enter final judgment, is no more an adjunct to the district court than was the bankruptcy judge in Stern.

In sum, section 636(c)'s authorization to enter final judgments is unconstitutional.

\section{A Court Should Never Defer to the Views or Reputation of Counsel in Deciding Whether to Approve a Class-Action Settlement.}

As part of his famous exposition on judicial independence, Chief Justice Marshall reminded us that "[t]he government of the United States has been emphatically termed a government of laws, and not of men." Marbury v. Madison, 5 U.S. (1 Cranch) 137, 163 (1803). And yet, the magistrate judge below approved a class-action settlement based 
not solely on his independent scrutiny of the law and facts, but instead in significant part on deference to the class lawyers' "judgment" that the settlement was a good deal. See Doc. 157, at 22. The magistrate judge went on to trumpet those lawyers' legal ability and personal integrity. Doc. 157, at 22-23; see also id. at 15, 16, 31-32 (similar statements). The magistrate judge's approach, we admit, was not unusual; many other cases have done the same thing, all but abdicating the judicial role to lawyers, and, sometimes, nearly fawning over their reputations in the course of settlement approval. ${ }^{6}$

NACA agrees with appellant Gunn that the magistrate judge's reliance on class counsel's recommendation to approve the settlement and on their stellar personal attributes was reversible error on the facts here. See Br. of Appellant 34-40. NACA asks the Court to go further and hold that under no circumstances may a court give weight to settling counsel's judgment about the wisdom of a class settlement or rely on class counsel's reputation in assessing a settlement's

${ }^{6}$ See, e.g., In re Vitamins Antitrust Litig., 305 F. Supp. 2d 100, 106 (D.D.C. 2004); Brotherton v. Cleveland, 141 F. Supp. 2d 894, 906 (S.D. Ohio 2001); Wattleton v. Ladish Co., 89 F.R.D. 677, 685 (E.D. Wis. 1981). 
fairness or legality. In NACA's view, that assessment is solely for the court.

We turn first to the magistrate judge's suggestion that he was bound by this Court's precedent. The Court's decision in Canupp v. Liberty Behavioral Healthcare Corp., 447 Fed. App'x. 976 (11th Cir. 2011) - accurately cited by the magistrate judge when he deferred to the "judgment ... of counsel," Doc. 157, at 22-is no barrier to the ruling NACA seeks here. First, Canupp is unpublished and, therefore, not binding. Second, the Court's precedential reversal of a class-action settlement approval in Holmes v. Continental Can Co., 706 F.2d 1144 (11th Cir. 1983), although acknowledging that courts have placed "great weight" on counsel's judgment, $i d$. at 1149, appears to have rejected that approach precisely because it undermines judicial independence in a context where independence is critical. "Reliance on counsel's opinion," Holmes explained, "tends to render the district court captive to the attorney and fosters rubber stamping by the court rather than the careful scrutiny which is essential in judicial approval 
of class action settlements." Id. at 1150 . Having cleared the precedential decks, we now turn to what the rule should be.

In conveying why the deference embraced by the district court should be rejected, first consider how such deference might apply in ordinary, one-on-one litigation. Assume that the judge is presented with a motion in limine. The plaintiff's brief argues that the evidence is not hearsay and therefore admissible, while the defendant's brief, naturally, argues that the evidence is hearsay and must be excluded. And suppose that, in ruling on the motion, the judge says, "This is a close case. Having read the briefs and reviewed the facts and law, I rule in the plaintiff's favor, deferring to the judgment of plaintiff's counsel and taking judicial notice of her fine reputation for first-rate legal analysis and integrity." This hypothetical ruling would almost certainly never occur in real life-because a judge is supposed to base her decisions solely on the law and facts, and decide cases independently—and, if it did, reversal would be quick and decisive. Turning to class-action settlements, there is more reason to be concerned about abdication of judicial independence and deference to 
counsel in that context than in traditional bi-polar litigation. There, the mass of plaintiffs — the absentees—have agreed to nothing because they have no relationship with their lawyer, and they have no way to monitor their lawyer's conduct and assure that she is acting in their interests. Class settlements therefore present the possibility of collusive (or at least sub-optimal) deals, in which the defendant maximizes its "purchase [of] res judicata," Bolin v. Sears, Roebuck \& Co., 231 F.3d 970, 976 (5th Cir. 2000), the class members receive very little (or, as in this case, zero), while, in exchange, plaintiffs' counsel receives "red-carpet treatment on fees." Weinberger v. Great $N$. Nekoosa Corp., 925 F.2d 518, 524 (1st Cir. 1991). ${ }^{7}$

Many courts that have deferred to the views of counsel have not provided a detailed rationale - generally saying only that settlement is favored and counsel is more familiar with the nuances of the case than they are. See, e.g., Trief v. Dun \& Bradstreet Corp., 840 F. Supp. 277, 281 (S.D.N.Y. 1993); Boyd v. Bechtel Corp., 485 F. Supp. 610, 622 (N.D.

${ }^{7}$ For a partial collection of judicial opinions and legal scholarship on the potential for break down in the agency relationship between lawyer and client in class actions, see Thorogood v. Sears, Roebuck \& Co., 627 F.3d 289, 294 (7th Cir. 2010). 
Cal. 1979). To be sure, once a class-action settlement occurs, the named parties are non-adverse, and judges do not have the lawyers' help in ferreting out the case's strengths and weaknesses as they do in other cases. So, perhaps judges think deference is appropriate when they perceive themselves to be in the dark.

But that the parties are non-adverse cuts the other way. After all, a Rule 23(e) fairness hearing can be "staged performance," jointly produced by class and defense counsel, at which "the court can't vindicate the class's rights because the friendly presentation means that it lacks essential information." Kamilewicz v. Bank of Boston Corp., 100 F.3d 1348, 1352 (7th Cir. 1996) (Easterbrook, J., joined by Manion, Rovner, and Wood, JJ., and Posner, C.J., dissenting from denial of rehearing en banc). The answer to that serious problem is not to make it worse by deferring to the lawyers, but to insist that the lower court probe the settling parties' assertions, listen to objectors (the only true adversaries), and "act[ as a fiduciary ... [to] serve as a guardian of the rights of absent class members." In re General Motors 
Corp. Pick-Up Truck Fuel Tank Prods. Liab. Litig., 55 F.3d 768, 785

(3d Cir. 1995) (citations omitted).

One element of the ruling below underscores why deference to counsel should be impermissible in the class settlement context. The magistrate judge's settlement approval was premised in part on the fact that class counsel "are well known to me," giving him a basis for praising their "exceptional legal abilities" and "utmost integrity." Doc. 157 , at 22 . But, like many class actions, this case was nationwide in scope, comprised of absentees (and their lawyers) who were unknown to the magistrate judge. Appellant Gunn, for instance, is from Ohio, Doc. 133, at 11, and his lawyer is from Washington, D.C., id. at 25-26. They could not, therefore, garner the "well-known-to-me" deference that the magistrate judge accorded class counsel.

NACA wants to be clear. It is not anti-class action. Indeed, it favors their vigorous use. Class actions are enormously useful tools for justice. For decades, they have compensated discrimination victims, reformed oppressive governmental institutions, and deterred a wide array of wrongful business conduct where individuals, acting alone, 
would not have had the means to sue on their own. See Thorogood, 627 F.3d at 294-95 (noting that class actions are "indispensable for the litigation of many meritorious claims"). But class actions can be abused, souring the public and political leaders, and jeopardizing the prospect of justice. It is for this reason that NACA has published its Standards and Guidelines for Litigating and Settling Consumer Class Actions, 255 F.R.D. 215 (2d ed. 2009), which are aimed at promoting class actions by curbing their misuse.

The magistrate judge here, like other courts approving classaction settlements, proclaimed that "the court should be hesitant to substitute its judgment for that of counsel." Doc. 157, at 22; see also, e.g., Williams v. Vukovich, 720 F.2d 909, 922-23 (6th Cir. 1983); Lopez v. City of Santa Fe, 206 F.R.D. 285, 292 (D.N.M. 2002). That rationale has a ring to it because, in some contexts, as in administrative law, see U.S. Postal Serv. v. Gregory, 534 U.S. 1, 7, 122 S. Ct. 431, 434 (2001), or appellate review of district-court fact finding, the law accords one public official primary decision making authority over another. 
But the law accords no deference to lawyers. Lawyers are charged by the adversary system to make arguments for clients, not to determine the law and facts. Put another way, contrary to the magistrate judge's understanding, it is exactly the role of a court to substitute its judgment for the judgments of lawyers. That is all the more true, as we have said, in the class settlement context, because of concerns that some lawyers, unless properly policed, might abandon their clients altogether.

In sum, this Court should hold that a court may never defer to settling counsel's views or reputation in determining whether a classaction settlement is fair and lawful.

\section{CONCLUSION}

The Court should reverse because the magistrate judge exercised power that the Constitution reserves to Article III judges. If the Court disagrees, it should reverse because the magistrate judge impermissibly deferred to class counsel's views and reputation in approving the settlement. 
Respectfully submitted,

Is/ Brian Wolfman

Brian Wolfman

Institute for Public Representation

Georgetown University Law Center

600 New Jersey Avenue, N.W.

Washington, D.C. 20001

(202) 661-6582

Counsel for amicus National Association of Consumer Advocates

June 25, 2012 


\section{CERTIFICATE OF COMPLIANCE}

I certify that this brief complies with the type-volume limitation set by Federal Rules of Appellate Procedure 29(d) and 32(a)(7)(B). This brief contains 6,997 words.

Is/ Brian Wolfman

Brian Wolfman 


\section{CERTIFICATE OF SERVICE}

I certify that on June 25, 2012, I filed the foregoing Brief of Amicus Curiae National Association of Consumer Advocates using the Electronic Case Files (ECF) system, which will send a Notice of Docket Activity (NDA) to all counsel who have registered to file and serve documents electronically (Attorney Filers). The NDA constitutes service on the following Attorney Filers:

Marie A. Borland

David T. Knight

Lara J. Tibbals

Hill, Ward \&Henderson

101 East Kennedy Blvd., Suite 3700

P.O. Box 2231

Tampa, FL 33601

Attorneys for Law Firm Defendants-Appellees

Michael T. Kirkpatrick

Public Citizen Litigation Group

1600 20th Street, NW

Washington, DC 20009

Attorney for Appellant Raymond Gunn

Lawrence S. Greenwald

Brian L. Moffet

Catherine A. Bledsoe

Gordon Feinblatt

233 East Redwood Street

Baltimore, MD 21202

Matthew A. Leish

D. Matthew Allen

Carlton Fields

P.O. Box 3239

Tampa, FL 33601

Attorneys for Defendant-Appellee CareOne Services, Inc. 
Victor Paladino

New York State Office of the Attorney General

The Capitol

Albany, NY 12224

Attorney for Amici Curiae State of New York and other states

I further certify that parties who are not represented by Attorney Filers have been served by first-class U.S. mail, postage prepaid, as follows:

James E. Felman

Katherine E. Yanes

Clarisse Moreno

Kynes, Markman \& Felman

P.O. Box 3396

Tampa, FL 33601

Attorneys for Plaintiffs-Appellees

Miranda L. Day and the Class

Is/ Brian Wolfman

Brian Wolfman 
No. 12-11887

\title{
UNITED STATES COURT OF APPEALS FOR THE ELEVENTH CIRCUIT
}

\author{
MIRANDA L. DAY, for herself \\ and all persons similarly situated, \\ Plaintiffs-Appellees,
}

V.

RAYMOND GUNN, Interested Party-Appellant,

V.

PERSELS \& ASSOCIATES, LLC; RUTHER \& ASSOCIATES,LLC; LEGAL ADVICE LINE, LLC; JIMMY B. PERSELS; NEIL J. RUTHER; ROBYN R. FREEDMAN; and CAREONE SERVICES, INC., Defendants-Appellees.

On Appeal from the United States District Court for the Middle District of Florida

REPLY BRIEF OF AMICUS CURIAE NATIONAL ASSOCIATION OF CONSUMER ADVOCATES

Brian Wolfman

Institute for Public Representation

Georgetown University Law Center

600 New Jersey Avenue, NW

Washington, D.C. 20001

(202) 661-6582

Counsel for Amicus Curiae 


\section{CERTIFICATE OF INTERESTED PERSONS AND CORPORATE DISCLOSURE STATEMENT}

Under Federal Rule of Appellate Procedure 26.1 and this Court's

Rule 26.1-1, undersigned counsel for amicus curiae National Association of Consumer Advocates certifies that he believes that the Certificate of Interested Persons and Corporate Disclosure Statement accompanying the Brief of Appellee CareOne Services, Inc., on August 22, 2012, is complete.

Is/ Brian Wolfman Brian Wolfman 


\section{TABLE OF CONTENTS}

CERTIFICATE OF INTERESTED PERSONS. . . . . . . . . . . . . C-1

TABLE OF CITATIONS. . . . . . . . . . . . . . . . . ii

ARGUMENT. . . . . . . . . . . . . . . . . . . . . . . . . 1

I. The Magistrate Judge Lacked Constitutional Authority

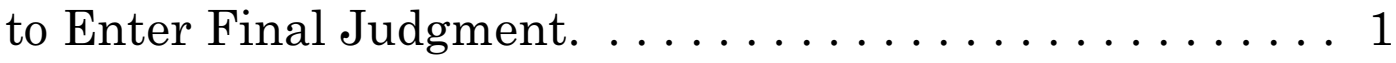

A. The Magistrate Judge Lacked Authority to

Enter Final Judgment Because the Absent

Class Members Did Not Provide Their

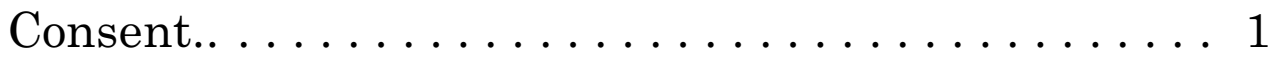

B. The Magistrate Judge Lacked Authority to

Enter Final Judgment Because the Absent

Class Members Were Not Notified That the

Named Plaintiff Was Relinquishing Their

Rights to an Article III Judge... . . . . . . . . 7

II. A Court Should Never Defer to the Views or Reputation

of Counsel in Deciding Whether to Approve a Class-

Action Settlement. . . . . . . . . . . . . . 10

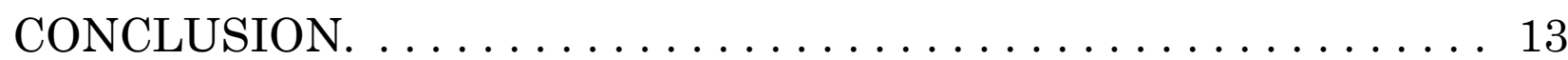


CERTIFICATE OF COMPLIANCE. . . . . . . . . . . . . . . 15

CERTIFICATE OF SERVICE. . . . . . . . . . . . . . 16 


\section{TABLE OF CITATIONS}

(Citations on which amicus primarily relies are preceded with an *.)

\section{CASES}

Amchem Products., Inc. v. Windsor,

521 U.S. 591, 117 S. Ct. 2231 (1997). . . . . . . . . . . . . . . 4

Dewey v. Volkswagen Aktiengesellschaft,

_ F.3d_, 2012 WL 1948970

(3d Cir. May 31, 2012).................. 2-3, 3

Eisen v. Jacquelin \& Carlisle,

417 U.S. 156, 94 S. Ct. 2140 (1974). . . . . . . . . . . . . . 5

Hall v. Sharpe,

812 F.2d 644 (11th Cir. 1987). . . . . . . . . . . . . . . . . 2

*Holmes v. Continental Can Co.,

706 F.2d $1144(11$ th 1983$) \ldots \ldots \ldots \ldots \ldots \ldots \ldots \ldots \ldots \ldots$. . . . 12

McNab v. J \& J Marine, Inc.,

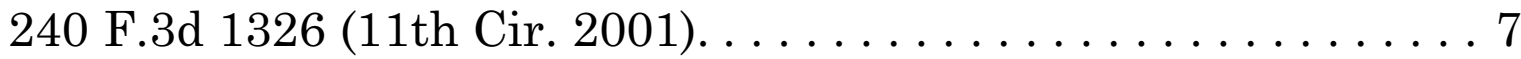

Mullane v. Central Hanover Bank \& Trust Co.,

339 U.S. 306 , 70 S. Ct. 652 (1950). . . . . . . . . . . . 8, 9, 10 
In re Nissan Motor Corp. Antitrust Litigation,

552 F.2d 1088 (5th Cir. 1977). . . . . . . . . . . . . . . 9

Northern Pipeline Construction Co. v. Marathon Pipe Line Co.,

458 U.S. 50, 102 S. Ct. 2858 (1982). . . . . . . . . . . . . . 4

Pacemaker Diagnostic Clinic, Inc. v. Instromedix, Inc.,

725 F.2d 537 (9th Cir. 1984) (en banc). . . . . . . . . . . . . . 2

*Phillips Petroleum Co. v. Shutts,

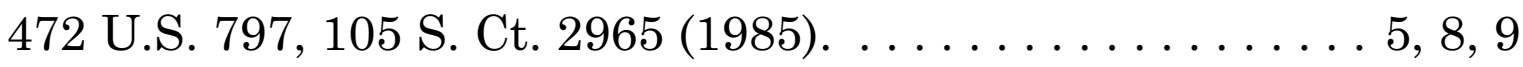

*Stern v. Marshall,

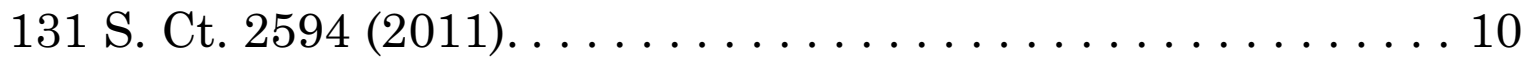

*Twigg v. Sears, Roebuck \& Co.,

153 F.3d 1222 (11th Cir. 1998). . . . . . . . . . . . . . . 8, 9

Williams v. General Electric Capital Automobile Lease, Inc.,

159 F.3d 266 (7th Cir. 1998). . . . . . . . . . . . . 3, 5, 8

\section{STATUTES}

28 U.S.C. $\S 636(b) \ldots \ldots \ldots \ldots \ldots \ldots \ldots \ldots \ldots \ldots \ldots \ldots \ldots \ldots$

28 U.S.C. $\S 636(\mathrm{c}) \ldots \ldots \ldots \ldots \ldots \ldots \ldots \ldots \ldots \ldots \ldots \ldots \ldots \ldots \ldots \ldots \ldots$

\section{MISCELLANEOUS}


Erwin Chemerinsky, "Formalism Without a Foundation: Stern $v$.

Marshall," 2011 S. Ct. Rev. 183, 209-212. . . . . . . . . . 10 


\section{REPLY BRIEF OF AMICUS CURIAE NATIONAL ASSOCIATION OF CONSUMER ADVOCATES}

In this reply brief, the National Association of Consumer

Advocates ("NACA") responds to the briefs filed by the appellees on the two issues addressed by NACA in its opening brief: (1) whether and under what circumstances a magistrate judge has constitutional authority to enter a final judgment approving a class-action settlement;

and (2) whether a district court may defer to the views and reputation of counsel who are proponents of a class-action settlement in deciding whether to approve that settlement. ${ }^{1}$

\section{ARGUMENT}

I. The Magistrate Judge Lacked Constitutional Authority to Enter Final Judgment.
A. The Magistrate Judge Lacked Authority to Enter Final Judgment Because the Absent Class Members Did Not Provide Their Consent.

1.a. NACA's opening brief (at 7-13) explained that the decisions

\footnotetext{
${ }^{1}$ Under Federal Rule of Appellate Procedure 29(c)(5), amicus certifies that no party's counsel authored this brief in whole or in part and that no party, party's counsel, or other person other than amicus or its counsel contributed money intended to fund the preparation or submission of the brief.
} 
of the courts of appeals upholding the constitutionality of 28 U.S.C. $\S$ 636(c) hinged not on the presumed consent of the parties, but on the actual, personal, and voluntary consent of the parties. As then-Judge Anthony Kennedy put it, the Constitution demands that section 636(c)'s "waiver of personal rights must, of course, be freely and voluntarily undertaken." Pacemaker Diagnostic Clinic, Inc. v. Instromedix, Inc., 725 F.2d 537, 542-43 (9th Cir. 1984) (en banc) (emphasis added); see also, e.g., Hall v. Sharpe, 812 F.2d 644, 647 (11th Cir. 1987) (explaining that "voluntary consent is crucial to [section 636(c)'s] procedure") (emphasis added). Thus, absent class members cannot constitutionally be bound to a class-action judgment under the purported authority of section 636(c) unless they, like all other litigants, have personally and voluntarily consented to a final adjudication before the magistrate judge.

The settling parties make no attempt to explain how the absent class members' conduct—or, more properly put, their inactivity—constitutes their personal and voluntary consent. Instead, they rely on two circuit court cases, Dewey v. Volkswagen 
Aktiengesellschaft, 681 F.3d 170 (3d Cir. 2012), and Williams v. General Elec. Capital Auto Lease, Inc., 159 F.3d 266, 268-70 (7th Cir. 1998), both of which are addressed in NACA's opening brief (at 13-16). With all respect, the problem with this argument is that, like the settling parties, neither case explains how no consent on the part of the absentees can equal their personal and voluntary consent. Rather, those cases reject NACA's position on efficiency grounds: that is, on the view that such a "radical result" would make it nearly impossible for magistrate judges to enter final judgments in class actions. See Dewey, 681 F.3d at 181; Williams, 159 F.3d at 269.

NACA's opening brief (at 9 n.3, 15) explained that the "radical result" argument was wrong on its own terms because (1) class-action judgments rarely are entered by magistrate judges—a point that the settling parties do not contest; (2) in some cases, the class members' consent could be sought, and (3) magistrate judges could still preside over class actions under 28 U.S.C. § 636(b). But more fundamentally, the settling parties overlook that Article III deliberately eschews efficiency in exchange for life-tenured, independent federal judges even 
when the result is tumultuous. See NACA Br. 15-16 (discussing result in Northern Pipeline Construction Co. v. Marathon Pipe Line Co., 458 U.S. 50, 102 S. Ct. 2858 (1982)).

b. CareOne asserts that if an absent class member prefers an Article III judge, she "can apply to the district court to intervene." CareOne Br. 52. That is true, but it supports NACA's position. If a class member intervenes and demands an Article III judge that effectively overrides any consent given to the magistrate judge by the named plaintiff-because the district judge and the magistrate judge cannot both enter a final judgment-leaving the "radical result" that CareOne claims to abhor. ${ }^{2}$

${ }^{2}$ Even assuming that intervention were a sensible alternative in principle, it makes no sense in this case because the class-action notice did not tell the absentees that they had a right to an Article III judge and that the named plaintiff proposed to relinquish it, rendering any intervention right illusory. See NACA Opening Br. 15, 21-22; infra at 710. CareOne's claim that the absent class members' opt-out rights negated their rights to an Article III judge fails for the same reason. See CareOne Br. 53 n.13. The class members here could not have opted out to preserve their rights to an Article III judge because they were not told about that right or that the class representative was trying to relinquish it. See Amchem Prods., Inc. v. Windsor, 521 U.S. 591, 628, 117 S. Ct. 2231, 2252 (1997) (observing that an opt-out right is meaningful only if class members "have the information or foresight 
c. CareOne claims that an absentee may also "raise a collateral attack" on the named plaintiff's consent to a non-Article III decision maker. CareOne Br. 52 (citing Williams, 155 F.3d at 269). But a rule encouraging collateral attacks makes no sense because it would leave open the possibility that judgments believed to be final could be rendered non-preclusive years after their entry. In any event, the potential for collateral attack is no reason not to protect the absentees' rights to an Article III judge in the first place.

2. As explained in NACA's opening brief (at 16-17), the Court could decide this appeal on the alternative (and narrower) ground that the entry of final judgment here was unconstitutional because Miranda Day's consent to the magistrate judge was entered solely on her own behalf, see Doc. 90 (May 23, 2011), well before she had any authority to act on the class members' behalf, which did not occur until the

\section{${ }^{2}$ (...continued)}

needed to decide, intelligently, whether to stay in or opt out"). Care One's argument is also wrong because the right to opt out is not a substitute for, but in addition to, the other rights guaranteed by the Constitution and Rule 23. See Phillips Petroleum Co. v. Shutts, 472 U.S. 797, 812, 105 S. Ct. 2965, 2974 (1985); Eisen v. Jacquelin \& Carlisle, 417 U.S. 156, 175-76, 94 S. Ct. 2140, 2151-52 (1974). 
magistrate judge certified the class as part of his settlement approval. Doc. 157 (Mar. 12, 2012).

None of the settling parties respond to this point directly. In what may be intended as an oblique response, however, Day says that "all parties consented to the jurisdiction of the magistrate judge." Day Br. 47 (emphasis added). But the document Day cites for that proposition, Doc. 88, is a consent form dated May 20, 2011, signed by Day's lawyer in the name of only one plaintiff, "Miranda L. Day"-without any indication that Day had (or even claimed) the authority to act on behalf of a class-which makes sense given that class counsel were not appointed until more than four months later. See Doc. 112, at 3 (Sept. 29, 2011). Thus, even assuming (incorrectly) that Miranda Day or her lawyers later possessed the authority, as representatives of a certified class, to consent to the entry of final judgment by a magistrate judge on behalf of the class members, they never exercised that authority, and this Court may reverse on that basis alone. 


\section{B. The Magistrate Judge Lacked Authority to Enter Final Judgment Because the Absent Class Members Were Not Notified That the Named Plaintiff Was Relinquishing Their Rights to an Article III Judge.}

NACA's opening brief (at 18-22) explains that even if 28 U.S.C. $\S 636(c)$ is constitutional as applied to class actions generally, its application in this case was unconstitutional because the absentees were not notified that they would be relinquishing their rights to an Article III decision maker and that a magistrate judge would enter final judgment. In general, we rely on our earlier arguments-which the settling parties largely ignore-and reply on only two points.

1. Day (but not the other appellees) asserts, unadorned by any authority, that because NACA's notice argument is not jurisdictional and was not raised below, it should not be addressed by this Court. Day Br. 51. The premise of this assertion is wrong. The failure of notice here concerns notice to the class members of their constitutional rights to an Article III judge, which appellees do not (and cannot) dispute presents a "jurisdictional question" that should be raised sua sponte even when no one brings it to the court's attention. McNab v. J\& J Marine, Inc., 20 F.3d 1326, 1328 (11th Cir. 2001); see NACA Opening Br. 6-7. 
Moreover, even if we indulge Day's counterfactual position, and view the notice issue as unrelated to the Article III issue, the issue would still be jurisdictional. An argument premised on a lack of notice could not have been raised by class members who, by definition, did not know that their rights were at stake. For that reason, without constitutionally adequate notice, a class-action judgment cannot have preclusive effect. See, e.g., Shutts, 472 U.S. at 811-12, 105 S. Ct. at 2974 (1985); Mullane v. Central Hanover Bank \& Trust Co., 339 U.S. 306 $314-15,70$ S. Ct. 652,657 (1950). As a result, a lack of notice is a proper basis for collateral attack, which presupposes that the defect was not raised in the underlying proceeding at all, see, e.g., Twigg $v$. Sears, Roebuck \& Co., 153 F.3d 1222 (11th Cir. 1998), and underscores that it can be raised for the first time on appeal.

2. Turning to the merits, the settling parties say that due process was satisfied because the settlement notice stated that the settlement hearing would be before the magistrate judge. Day Br. 51 (citing Williams, 159 F. 3d at 270). But cherry-picking one ambiguous reference to the magistrate judge buried on page seven of a eight-page, 
small-print notice, see Doc. 111-1, does not extricate the settling parties from their due-process problem. NACA's opening brief (at 20-21) showed that a reader of the entire notice likely would not know the identity of the final decision maker. This Court may reverse on that narrow basis alone. See, e.g., Twigg, 153 F.3d at 1227-28 (describing the considerable demands of due process in the class-action notice context). But the settling parties ignore the bigger problem. Due process requires that class members-who are lay people-be informed of the action and the plaintiffs' rights in it." Shutts, 472 U.S. at 811-12, 105 S. Ct. at 2974 (quoting Mullane, 339 U.S. at 314-15, 70 S. Ct. at 657 (emphasis added)); see also In re Nissan Motor Corp. Antitrust Litig., 552 F.2d 1088, 1103-05 (5th Cir. 1977) (class-action settlement notice "will be the [absentees'] primary, if not exclusive, source of information for deciding how to exercise their rights"). The right at issue here is the constitutional right to an Article III decision maker, and neither that right nor that Miranda Day was throwing that right to the winds is mentioned anywhere in the notice. 
Put most charitably, what the settling parties did here was the "mere gesture" at notice condemned by the Supreme Court over sixty years ago. Mullane, 339 U.S. at 315, 70 S. Ct. at 657 (1950). For this reason as well, the decision below should be reversed. ${ }^{3}$

\section{A Court Should Never Defer to the Views or Reputation of Counsel in Deciding Whether to Approve a Class-Action Settlement.}

NACA's opening brief (at 29-37) argued that a court should never do what the magistrate judge did here: give weight to settling counsel's judgment about the wisdom of a class settlement and rely on class counsel's reputation in assessing a settlement's fairness or legality.

On this issue, the settling parties' briefs focus almost exclusively on trying to prove that the case law authorized the magistrate judge's overt deference to class counsel's views and reputation. Persels Br. 36-

${ }^{3}$ With regard to our argument that section 636(c) is facially unconstitutional, we rest almost entirely on our opening brief (at 22-29) and reply on just one point. CareOne has misinterpreted our reliance on Stern v. Marshall, 131 S. Ct. 2594 (2011). We agree that the result in Stern is narrow and properly could be described as "sui generis." See CareOne Br. 56 \& n.16. As our opening brief (at 27-28) noted, however, Stern's reasoning draws into serious question the continuing relevance of consent as a factor in separation-of-powers analysis. See also Erwin Chemerinsky, "Formalism Without a Foundation: Stern v. Marshall," 2011 S. Ct. Rev. 183, 209-212. 
37; Day Br. 42-45; CareOne Br. 47-49. The settling parties do not dispute that the only on-point published opinion of this Court appears to reject the magistrate judge's approach because it renders the judge "captive to the [class] attorney and fosters rubber stamping," at odds with the "careful scrutiny" that is "essential" when courts review classaction settlements. Holmes v. Continental Can Co., 706 F.2d 1144, 1150 (11th Cir. 1983). CareOne seeks to distinguish Holmes, saying that it authorizes deference in some cases, just not where the settlement is unfair and counsel lacks knowledge of the case (as in Holmes). CareOne Br. 49-50.

NACA disagrees. The better reading of Holmes is that, rather than endorsing deference to counsel in any type of case, it was describing some of the existing case law when it noted that deference has been viewed as discretionary. That is the only sensible way to reconcile Holmes with its forceful language quoted in part above and its detailed list of "general concerns" with deference to class counsel. See Holmes, 706 F.2d at 1150. 
In any event, the Court should reject the settling parties' efforts to attribute to Holmes the illogical conclusion that deference to the views and reputation of counsel is appropriate when the settlement is fair and class counsel is well informed, but inappropriate when the settlement is unfair or collusive. See Day Br. 45; CareOne Br. 49-50. Deference is used, as it was below, in deciding whether a settlement is fair, adequate, and reasonable. So, when the magistrate judge said that he was relying on class counsel's "judgment" that the settlement was a good deal, Doc. 157, at 22, and when he trumpeted class counsel's "exceptional legal abilities" and "utmost integrity," $i d$. , he had to be taking those things into account in reaching his decision. Otherwise, his reliance on them would have served no purpose.

As noted, the settling parties make almost no effort to defend deference to counsel's views and reputation in principle. After all, it is hard to defend a doctrine that is at war with judicial independence. See Holmes, 706 F.2d at 1150. In one respect, appellees' silence is particularly conspicuous and bears mention. NACA's opening brief (at 35) observed that the settlement approval below was premised in part 
on the magistrate judge's statement that class counsel "are well known to me," and NACA noted that objector Gunn's lead lawyer was unable to receive the same special recognition-creating an imbalance among the parties having nothing to do with the merits of the case. That statement underscores why deference to counsel in class actions undermines judicial independence and should not be permitted under any circumstances.

\section{CONCLUSION}

The Court should reverse because the magistrate judge exercised power that the Constitution reserves to Article III judges. If the Court disagrees, it should reverse because the magistrate judge impermissibly deferred to class counsel's views and reputation in approving the settlement. 


\author{
Respectfully submitted, \\ /s/ Brian Wolfman \\ Brian Wolfman \\ Institute for Public Representation \\ Georgetown University Law Center \\ 600 New Jersey Avenue, N.W. \\ Washington, D.C. 20001 \\ (202) 661-6582
}

Counsel for amicus National Association of Consumer Advocates

September 10, 2012 


\section{CERTIFICATE OF COMPLIANCE}

Under the type-volume limitation set by Federal Rules of

Appellate Procedure 29(d) and 32(a)(7)(B), an amicus brief generally is limited to 7,000 words. The Federal Rules of Appellate Procedure do not contain a word limit for amicus reply briefs, which may only be filed with the court's permission. See Fed. R. App. P. 27(f). An appellant's reply brief may not exceed one-half the length of a principal brief. See Fed. R. App. P. 32(a)(7)(B)(ii). Applying the same one-half ratio to an amicus reply brief would result in a limit of 3,500 words. This brief contains 2,591 words.

/s/ Brian Wolfman

Brian Wolfman 


\section{CERTIFICATE OF SERVICE}

I certify that on September 10, 2012, I filed the foregoing Brief of Amicus Curiae National Association of Consumer Advocates using the Electronic Case Files (ECF) system, which will send a Notice of Docket Activity (NDA) to all counsel who have registered to file and serve documents electronically (Attorney Filers). The NDA constitutes service on the following Attorney Filers:

Marie A. Borland

David T. Knight

Lara J. Tibbals

Hill, Ward \&Henderson

101 East Kennedy Blvd., Suite 3700

P.O. Box 2231

Tampa, FL 33601

Attorneys for Law Firm Defendants-Appellees

Michael T. Kirkpatrick

Public Citizen Litigation Group

1600 20th Street, NW

Washington, DC 20009

Attorney for Appellant Raymond Gunn

Lawrence S. Greenwald

Brian L. Moffet

Catherine A. Bledsoe

Gordon Feinblatt

233 East Redwood Street

Baltimore, MD 21202

Matthew A. Leish

D. Matthew Allen

Mac R. McCoy

Carlton Fields

P.O. Box 3239

Tampa, FL 33601 
Attorneys for Defendant-Appellee CareOne Services, Inc.

Victor Paladino

New York State Office of the Attorney General

The Capitol

Albany, NY 12224

Attorney for Amici Curiae State of New York and other states

I further certify that parties who are not represented by Attorney Filers have been served by first-class U.S. mail, postage prepaid, as follows:

James E. Felman

Katherine E. Yanes

Clarisse Moreno

Kynes, Markman \& Felman

P.O. Box 3396

Tampa, FL 33601

Attorneys for Plaintiffs-Appellees

Miranda L. Day and the Class

Is/ Brian Wolfman

Brian Wolfman 